\title{
Ecos da leitura
}

\author{
Ligia Gonçalves Diniz* \\ Patricia Trindade Nakagome**
}

O eco, como se sabe, é uma reflexão do som que demora um pouco a chegar ao ouvinte após sua emissão. A leitura, de modo semelhante, é o processo que une o texto e seu sentido efetivado em cada pessoa. Em ambos, essa distância entre o verbalizado e o apreendido parece materializar uma mera identidade. Mas há sempre o desconhecido que caracteriza e separa os dois atos: a natureza da emissão, a característica do meio de propagação, a disposição da recepção.

Eco e leitura se aproximam. No caso de nosso dossiê, propomos o desdobramento de um sobre o outro, no modo como a leitura se espalha, muitas vezes revelando modificações no que entendemos como sua forma primordial. Afinal, a leitura vai além da ação de um ser solitário segurando seu livro. Mais ainda, vai além do que supomos sobre essa cena, incapazes que somos de saber aquilo que se passa pela cabeça e pelo corpo de quem lê. Assim, pensar a leitura, nos seus ecos ao longo do tempo e nos diferentes espaços, é sempre um exercício de abertura ao outro, de entrega à singularidade do que ele vê, entende, sente. Não raro, nós também nos descobrimos o outro nesse processo misterioso com o texto.

Lembremos o desfecho de "Felicidade clandestina" de Clarice Lispector: "Não era mais uma menina com um livro: era uma mulher com o seu amante." (2016, p. 396). Numa única frase, está sintetizada a relação visceral entre a leitora e a obra, a capacidade do texto de despertar o desejo e refundar a identidade. A menina que tem o livro nas mãos já não é mais a coitada que não pode comprá-lo, ela se torna a amante do livro que é apenas dela. Não que o fosse por posse, mas por um direito que se imortalizava: "pelo tempo que eu quisesse" (Lispector, 2016, p. 395). E não é assim toda a relação de prazer que estabelecemos com o texto? Podemos nos valer dele até o limite da nossa saciedade, abandonando-o logo ou demorandonos nas páginas. O mesmo texto que pode ser de muitos é apenas nosso, no modo como nos entregamos a ele.

\footnotetext{
Ligia Gonçalves Diniz é doutora em Teoria Literária e Literaturas pela Universidade de Brasília (UnB) e pós-doutoranda na Universidade Federal de Minas Gerais (UFMG), Belo Horizonte, MG. E-mail: ligiadiniz@gmail.com.

* Patricia Trindade Nakagome é professora adjunta do Departamento de Teoria Literária e Literaturas da Universidade de Brasília (UnB), Brasília, DF. E-mail: patricia.nakagome@gmail.com.
} 
Neste dossiê, selecionamos textos bastante diversos no modo de trabalhar a relação entre o leitor e a obra. A leitura, comumente entendida e praticada como esse gesto silencioso de percorrer as palavras com os olhos, ecoa aqui em muitos sons e formas.

Inicialmente, Natalia Borges Polesso, em "O leitor no espaço: jogo e ocupação das cidades" aborda a noção de um leitor especializado e propõe um jogo literário. Nesse artigo que reúne aquilo que está consolidado na teoria e o que se abre para o jogo, temos a discussão sobre o que está fixo no texto e o que se modifica sempre na leitura. Também entendemos que a ocupação da cidade narrativa é uma dimensão da ocupação das cidades. Na sequência, o espaço segue como chave importante para se pensar a leitura literária. Em "Literatura em alto e bom som: experiência e materialidade em leituras literárias coletivas", Mei Hua Soares trata de práticas de leitura em um grupo teatral e em salas de aula, investigando como as vantagens da leitura coletiva em voz alta poderiam alimentar o ambiente escolar, geralmente voltado para a leitura silenciosa. Também passando pelo teatro, Carlos Gontijo Rosa, em "Escrito para a cena barroca: a contextualização histórica na leitura contemporânea de textos dramáticos antigos” parte das peças mitológicas de Antônio José da Silva para discutir a leitura de textos dramáticos antigos na contemporaneidade. $\mathrm{O}$ autor reivindica a importância de se considerar o contexto de produção das obras, comumente deixados de lado pelo leitor atual.

Em "Adeus, cavalo de Nuno Ramos: quando o corpo vibra e o texto estremece", a obra analisada por Irma Caputo também flerta com o texto teatral. Na leitura do performático Adeus, cavalo (2017) de Nuno Ramos, a autora questiona os limites da representação literária, propondo a linguagem como forma de vida e defendendo o papel ativo do leitor. Tais aspectos são também explorados no artigo "O VisualMaterial de 'Cidade/City/Cité”" de Tiago Santos, em que são discutidas as diferentes recriações do poema de Augusto de Campos. A metamorfose do texto, materializada em diferentes formas leituras, é indicativa das mudanças no próprio espaço das cidades.

A ação de leitores sobre o texto também fica bastante evidente em "Transformações do literário quando a literatura que importa é feita pelos fãs" de Sayonara Amaral de Oliveira. A partir da análise do universo das fanfictions, a autora mostra de que modo os fãs criam um capo literário alternativo, com critérios e protocolos de leitura próprios, muitas vezes desconhecidos pela crítica especializada. Por fim, também tratando de outro objeto tão comum em nosso tempo, mas nem sempre observado com a devida atenção, temos o artigo que analisa a materialidade de livros digitais: "A caracterização dos livros digitais a partir da sua materialidade" de Thaís Cristina Martino Sehn, Suely Fragoso e José Luís Farinatti Aymone. A partir de uma análise detalhada, fica evidente como o livro digital está aberto a mudanças, mas guarda muitas convenções e tradições do livro impresso.

A partir da brevíssima síntese dos artigos, podemos notar quão profícuo é o tema da leitura nos estudos literários. A leitura é uma dimensão do espaço, ma- 
terializada no texto, aberta para corpos e cidades; a leitura é uma dimensão do tempo, necessário para percorrer uma história e único no seu desdobramento em cada sujeito; a leitura é uma dimensão do poder, inscrito nas dinâmicas sociais que determinam o que deve ser lido e na promessa ingênua, mas verdadeira, de mudar o mundo.

Quando tratamos de leitura em toda sua abrangência, é necessário reconhecer a força que une o leitor e o texto e o mistério que os separa. São muitas as variáveis num processo que envolve pessoas diante de textos variados (orais ou escritos, contemporâneos ou antigos, canônicos ou populares). Nesse cenário complexo, talvez o único ponto fundamental seja perceber que o leitor está muito longe da passividade que por muito tempo se reconheceu nele. Podemos pensar na mesma linha do que aponta Jacques Rancière sobre o espectador: "Ser espectador não é condição passiva que deveríamos converter em atividade. É nossa situação normal. [...] Todo espectador é já ator de sua história; todo ator, todo homem de ação, espectador da mesma história." (2012, p. 21). Fugindo à dualidade simplista de ação e passividade, o filósofo defende o lugar ativo de todos nós na construção de sentidos. Isso é válido para o espectador sentado no teatro ou para o leitor com o livro nas mãos.

Na contemporaneidade, como vimos em nosso dossiê, a ação do leitor se faz agora materialmente mais evidente. Mas o fato é que a leitura nunca foi um processo passivo, sempre deixando seus vestígios nos corpos e na imaginação. Diferentemente do som do eco, que pode culminar em silêncio, os ecos da leitura, com a passagem do tempo, se fazem cada vez mais audíveis.

\section{Referências}

LisPector, Clarice. Todos os contos. Rio de Janeiro: Rocco, 2016.

RANCIÈre, Jacques. O espectador emancipado. São Paulo: Martins Fontes, 2012. 